\title{
Mass balance of East Antarctic glaciers and ice shelves from satellite data
}

\author{
ERIG RigNot \\ Fet Propulsion Laboratory, California Institute of Technology, 4800 Oak Grove Drive, Pasadena, CA 91109-8099, U.S.A.
}

\begin{abstract}
The velocity and mass discharge of nine major East Antarctic glaciers not draining into the Ross or Filchner-Ronne Ice Shelves is investigated using interferometric synthetic aperture radar (InSAR) data from the European Remote-sensing Satellite 1 and 2 (ERS-1/2) and RADARSAT-1. The glaciers are: David, Ninnis, Mertz, Totten, Scott, Denman, Lambert, Shirase and Stancomb-Wills. InSAR is used to locate their grounding line with precision. Ice velocity is measured with either InSAR or a speckle-tracking technique. Ice thickness is deduced from prior-determined ice-shelf elevation assuming hydrostatic equilibrium. Mass fluxes are calculated both at the grounding line and at a flux gate located downstream. The grounding-line flux is compared to a mass input calculated from snow accumulation to deduce the glacier mass balance. The calculation is repeated at the flux gate downstream of the grounding line to estimate the average bottom melt rate of the ice shelf under steady-state conditions. The main results are: (1) Grounding lines are found several tens of $\mathrm{km}$ upstream of prior-identified positions, not because of a recent ice-sheet retreat but because of the inadequacy of prior-determined grounding-line positions. (2) No gross imbalance between outflow and inflow is detected on the nine glaciers being investigated, with an uncertainty of $10-20 \%$. Prior-determined, largely positive mass imbalances were due to an incorrect localization of the grounding line. (3) High rates of bottom melting $\left(24 \pm 7 \mathrm{~m}\right.$ ice $\left.\mathrm{a}^{-1}\right)$ are inferred near grounding zones, where ice reaches the deepest draft. A few glaciers exhibit lower bottom melt rates $\left(4 \pm 7 \mathrm{~m}\right.$ ice $\left.\mathrm{a}^{-1}\right)$. Bottom melting, however, appears to be a major source of mass loss on Antarctic ice shelves.
\end{abstract}

\section{INTRODUGTION}

The state of mass balance of the vast majority of Antarctic glaciers is not known at present. This incomplete knowledge casts doubt on any estimate of the contribution of the Antarctic ice sheet to global sea-level rise. No change in icesheet elevation is detected in the vast interior of the ice sheet by European Remote-sensing Satellite (ERS) radar altimetry, except perhaps in the Amundsen Sea sector of West Antarctica (Wingham and others, 1998). These results, however, which are limited in spatial resolution to about $250 \mathrm{~km}$, do not provide any indication of the state of mass balance of the glaciers at low elevation, along the coast. In Greenland, recent results from airborne laser altimetry show that the ice-sheet interior is more or less in balance with accumu- lation, but large coastal sectors are thinning rapidly, with thinning concentrated in channels occupied by fast-moving outlet glaciers (Krabill and others, 2000). Similar studies conducted along the coastal sectors of Antarctica are timely.

Several approaches have been used to determine the mass balance of Antarctic glaciers, all with their own advantages and limitations. The approach considered here is commonly referred to as the mass-budget method. It compares mass accumulation in the interior with mass discharge across a flux gate. The difference between these two large values determines whether the glacier as a whole is losing or gaining mass. Recent advances in satellite radar interferometry (InSAR) mapping of grounding lines and ice velocity (Rignot and others, 1997), topographic mapping of the ice sheet (Bamber and Bindschadler, 1997) and digital mapping of snow accu-

Table 1. Mapping of East Antarctic glaciers using ERS and RSAT

\begin{tabular}{lccc}
\hline Glacier & $\begin{array}{c}\text { ERS velocity } \\
\text { (ERS-1/2 orbit pairs) }\end{array}$ & $\begin{array}{c}\text { RSAT velocity } \\
\text { (orbit pair) }\end{array}$ & $\begin{array}{c}\text { ERS grounding line } \\
\text { (ERS-1/2 orbit pairs) }\end{array}$ \\
\hline David & $24676-5003,24765-5092$ & - & $23763-4090,24765-5092$ \\
Ninnis & $24838-5165$ & - & $24838-5165,25339-5666$ \\
Mertz & $24967-5294$ & - & $24967-5294,25468-5795$ \\
Totten & $24868-5195$ & - & $24868-5195,24367-4694$ \\
Denman & $24840-5167$ & - & $24339-4666,23838-4165$ \\
Scott & $24840-5167$ & - & $24339-4666,23838-4165$ \\
Lambert & $23853-4180,24436-4763$ & $10196-9853$ & $23810-4137,24311-4638$ \\
Shirase & $24766-5715$ & $10183-9840$ & $24766-5715,25267-5714$ \\
Stancomb-Wills & $22482-2809,24497-4824$ & $10208-9865$ & $22482-2809,24486-4813$ \\
\hline
\end{tabular}




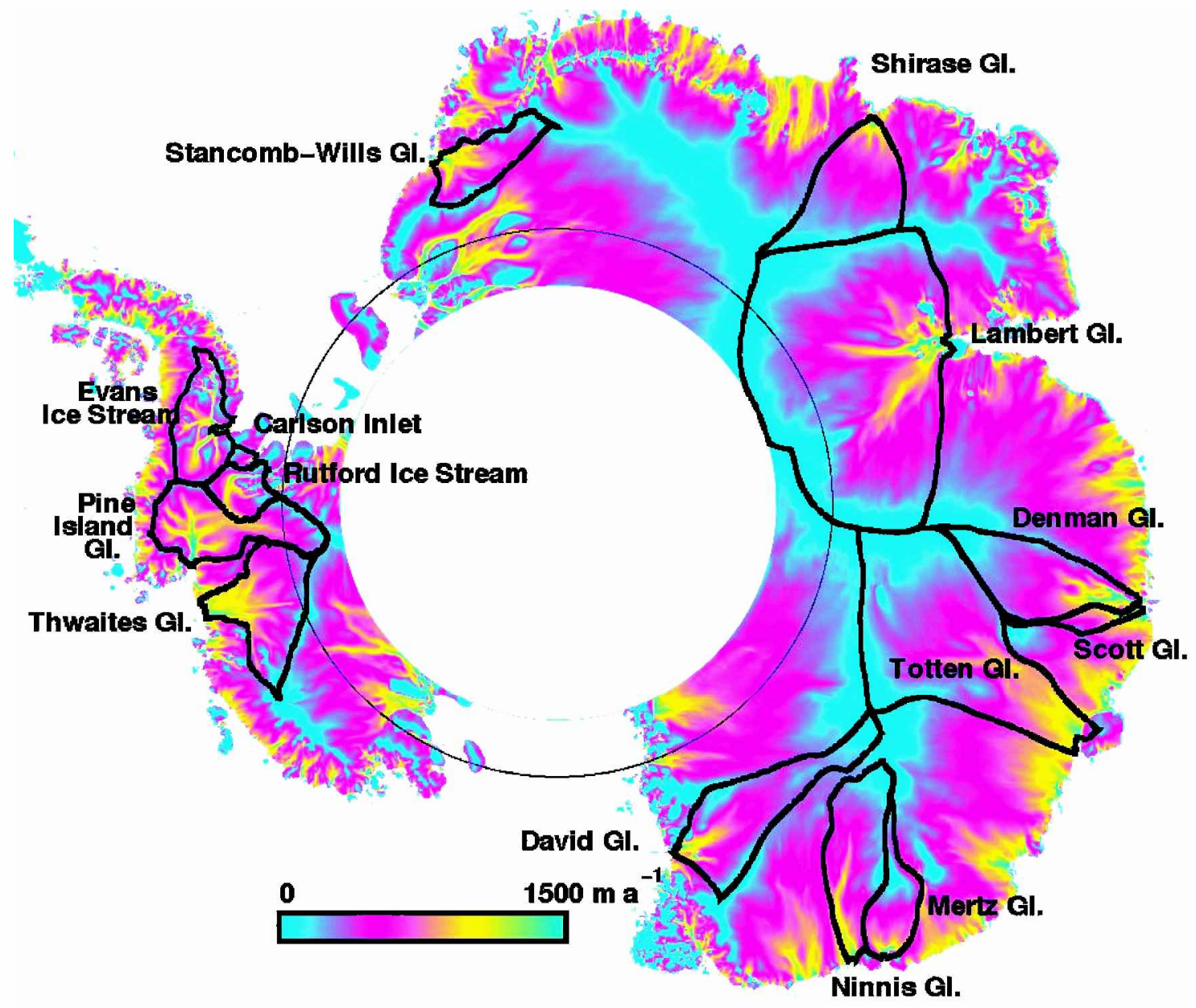

Fig. 1. Balance velocity (personal communication from f. L. Bamber, 2000) on a logarithmic scale showing the drainage basins of nine East Antarctic glaciers, on a polar stereographic grid. The drainage basins of five West Antarctic glaciers, studied with the same methodology but not discussed here, are shown for reference.

mulation (Vaughan and others, 1999; Giovinetto and Zwally, 2000) are prompting a revision of earlier mass-budget assessments of Antarctic glaciers. In this study, we present a first step toward this modern revision. InSAR is used to map the location of grounding lines, ice velocity in vector form, and surface topography of nine major outlet glaciers of East Antarctica that do not drain into the Ross or Filchner-Ronne Ice Shelves. The results are used to estimate the mass fluxes and mass balance of the glaciers, and the rates of basal melting of the ice shelves in front of them under steady-state conditions.

\section{METHODS}

This study combines InSAR data (Table 1) with prior-determined digital elevation maps (DEMs) and accumulation maps of Antarctica.

\section{Topography and accumulation}

Topography has four main usages: (1) to remove the topographic signal from InSAR measurements of ice velocity and grounding-line position; (2) to rectify and georeference the InSAR products onto an Earth-fixed grid; (3) to estimate ice thickness from ice-shelf elevation assuming hydrostatic equilibrium; and (4) to delineate the glacier drainage basins.

Several DEMs of Antarctica have been produced in recent years. The RADARSAT-1 (RSAT) Antarctic Mapping Project (RAMP) DEM (Liu and others, 1999), used to control the mosaicking of RADARSAT data, was not found to be useful for this study. Although it offers improved mapping of the coastal range, its accuracy is poor on floating ice where old cartography was used. This study uses the DEM of Antarctica derived from ERS radar altimetry alone (Bamber and Bindschadler, 1997), which is accurate at the meter level on the nearly flat surface of large ice shelves. Performance decreases rapidly over sloping terrain, near mountain ranges or at high latitude where the density of crossover points is low. In some cases, ERS radar altimetry had to be supplemented by an InSAR-derived DEM of the glacier (Table 1).

Table 2. Mass discharge of East Antarctic glaciers at the grounding line, $\phi_{\mathrm{GL}}$, and mass input from snow accumulation, $\phi_{\mathrm{A}}$, over a drainage basin of area $A$. $H$ and $V$ are, respectively, the glacier-center thickness and velocity at the grounding line

\begin{tabular}{|c|c|c|c|c|c|}
\hline Glacier & $\begin{array}{l}H \\
\mathrm{~m}\end{array}$ & $\begin{array}{c}V \\
\mathrm{ma}^{-1}\end{array}$ & $\begin{array}{c}\phi_{\mathrm{GL}} \\
\mathrm{km}^{3} \text { ice } \mathrm{a}^{-1}\end{array}$ & $\begin{array}{c}A \\
\mathrm{~km}^{2}\end{array}$ & $\begin{array}{c}\phi_{\mathrm{A}} \\
\mathrm{km}^{3} \text { ice } \mathrm{a}^{-1}\end{array}$ \\
\hline David & 3000 & 500 & $15.4 \pm 2$ & 212025 & $16.4 \pm 4$ \\
\hline Ninnis & 1600 & 900 & $21.9 \pm 3$ & 170550 & $24.8 \pm 1$ \\
\hline Mertz & 1350 & 850 & $19.8 \pm 2$ & 83080 & $21.3 \pm 0$ \\
\hline Totten & 2100 & 900 & $69.9 \pm 7$ & 534730 & $68.8 \pm 10$ \\
\hline Scott & 1200 & 500 & $9.2 \pm 2$ & 27340 & $10.9 \pm 3$ \\
\hline Denman & 2000 & 1600 & $35.1 \pm 5$ & 176240 & $37.4 \pm 9$ \\
\hline Lambert & 3000 & 800 & $57.5 \pm 5$ & 953670 & $55.2 \pm 1$ \\
\hline Shirase & 900 & 2300 & $15.1 \pm 3$ & 195670 & $16.9 \pm 0$ \\
\hline Stancomb-Wills & 1200 & 700 & $16.6 \pm 2$ & 98710 & $15.7 \pm 2$ \\
\hline Total & & & $260.5 \pm 11$ & 2452020 & $267.4 \pm 15$ \\
\hline
\end{tabular}



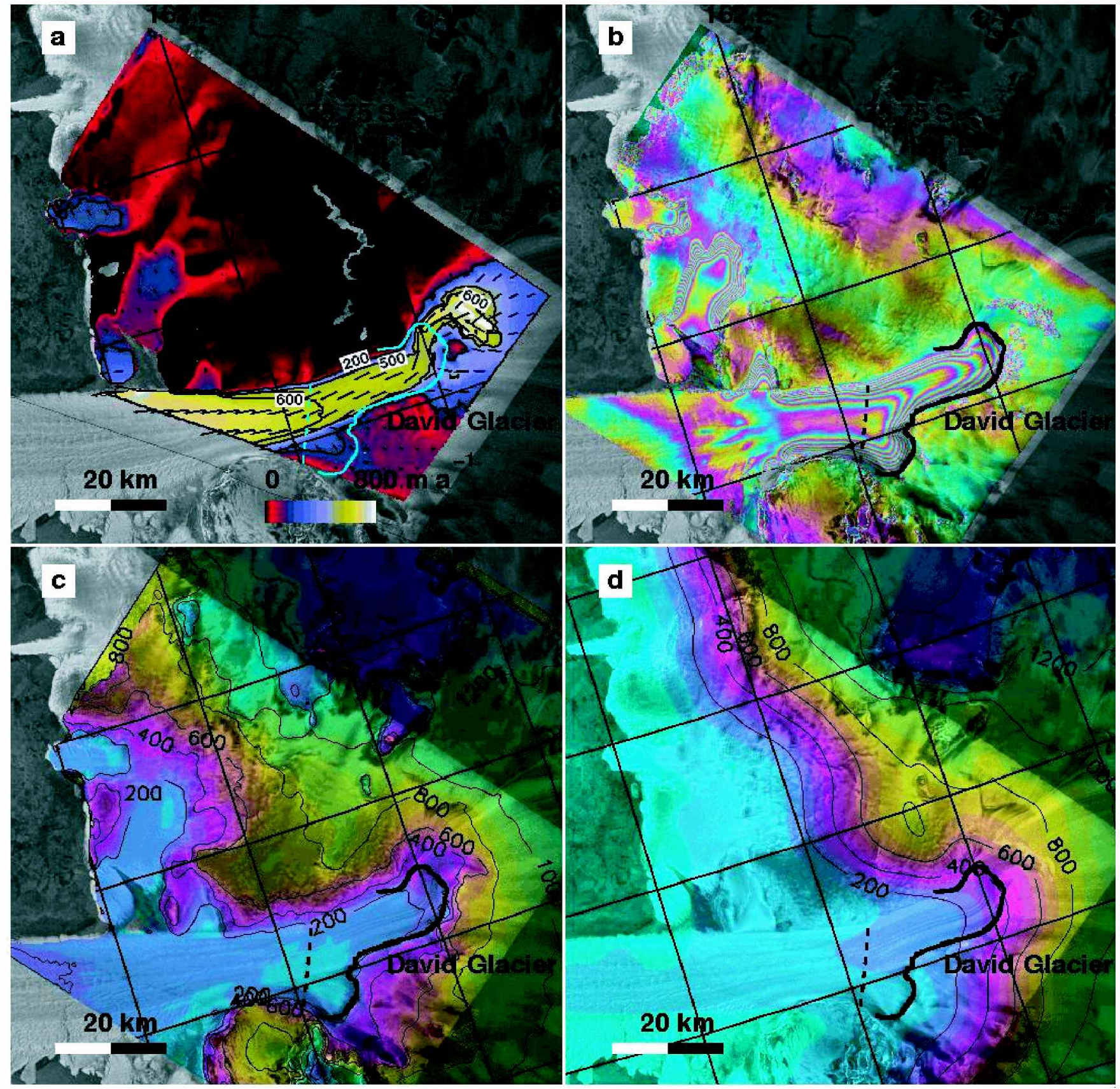

Fig. 2. David Glacier,Victoria Land: ( a) vector velocity map ( $m a^{-1}$ ) derived from ERS; (b) grounding-line position and tidal motion derived from ERS InSAR (each color cycle represents a $30 \mathrm{~mm}$ increment in vertical displacement of the ice surface due to changes in oceanic tide); surface topography (200 m contour) derived from (c) ERS InSAR and (d) ERS radar altimetry. The grounding-line and basal-melt flux gates are, respectively, shown in blue and dotted blue in (a), and black and dotted black in ( $c$, d). Latitude is plotted every $0.25^{\circ}$. Longitude is plotted $1^{\circ}$

Ice thickness is deduced from the ERS DEM (referenced to sea level using the OSU 91 geoid model) by multiplying the ice-shelf elevation by 8.05. This heuristic is based on a comparison of ice-sounding radar measurements with DEM elevations on Pine Island and Thwaites Glaciers (Rignot, 2001). The multiplicative coefficient reflects the density profile of ice and sea water, as well as geoidal height offsets. Errors in geoid height could be $\pm 10 \mathrm{~m}$ (e.g. Jenkins and Doake, 1991), thus inducing uncertainties in ice thickness of $\pm 100 \mathrm{~m}$ from hydrostatic equilibrium. Errors in the density profile of ice and sea water are likely less significant. Few measurements of ice thickness are available at the grounding line of East Antarctic glaciers for comparison. A detailed examination of the BEDMAP (Lythe and others, 2000) reveals a complete lack of thickness data on the float- ing sections of Totten, Denman, Shirase, Stancomb-Wills and Ninnis Glaciers. Three measurement points on Mertz Glacier Tongue indicate an underestimation of ice thickness by $3 \%$ or $30 \mathrm{~m}$. On Lambert Glacier, 17 data records indicate an overestimation of ice thickness by $3 \%$ or $57 \mathrm{~m}$. Ice-thickness data records exist in this area both above and below the grounding line, but not at the grounding line, which is the zone of confluence of Mellor, Fisher and Lambert Glaciers, and hence where ice is the thickest. Based on this limited set of comparisons, and potential uncertainties in the geoid, ice thickness employed in this study has an uncertainty of 100 (high-quality topographic information and existence of discrete thickness records) to $200 \mathrm{~m}$ (lower-quality topography and no thickness records).

Drainage basins are drawn from the end-points of the 
Table 3. Basal melt rates of East Antarctic glaciers calculated near the grounding line assuming steady-state conditions as the difference between the grounding-line flux, $\phi_{\mathrm{GL}}$, minus the ice flux at a gate located downstream, $\phi_{\mathrm{BM}}$, divided by the ice-shelf area, $A$, in between

\begin{tabular}{lcccc}
\hline Glacier & \multicolumn{1}{c}{$\begin{array}{c}\text { GL } \\
\mathrm{km}^{3} \text { ice } \mathrm{a}^{-1}\end{array}$} & $\begin{array}{c}\mathrm{km}^{2} \\
\end{array}$ & $\begin{array}{c}\phi_{\mathrm{BM}} \\
\mathrm{km}^{3} \text { ice } \mathrm{a}^{-1}\end{array}$ & $\begin{array}{c}\dot{B} \\
\mathrm{~m} \mathrm{ice} \mathrm{a}^{-1}\end{array}$ \\
\hline David & $15.4 \pm 2$ & 362 & $5.0 \pm 0.5$ & $29 \pm 6$ \\
Ninnis & $21.9 \pm 3$ & 407 & $20.2 \pm 2$ & $4 \pm 8$ \\
Mertz & $19.8 \pm 2$ & 375 & $13.1 \pm 1$ & $18 \pm 6$ \\
Totten & $69.9 \pm 7$ & 1030 & $49.5 \pm 6$ & $20 \pm 9$ \\
Scott & $9.2 \pm 2$ & 482 & $1.9 \pm 0.5$ & $15 \pm 5$ \\
Denman & $31.9 \pm 5$ & 616 & $14.9 \pm 2$ & $28 \pm 9$ \\
Lambert & $57.5 \pm 5$ & 913 & $28.4 \pm 2$ & $32 \pm 5$ \\
Stancomb-Wills & $16.6 \pm 2$ & 465 & $14.8 \pm 2$ & $4 \pm 6$ \\
& & & & \\
\hline
\end{tabular}

Notes: Net accumulation in between gates, $\delta \phi_{\mathrm{A}}$, is typically much less than $1 \mathrm{~m} \mathrm{a}^{-1}$ and is neglected in the calculation. No estimate of basal melting could be obtained for Shirase Glacier.

flux gates, following the line of steepest slope (Fig. 1). The drainage areas and corresponding mass fluxes presented here do not necessarily compare to those published in the past, because those estimates typically depend on the width and location of the selected output gates. This is especially true in the case of large glacier fronts where there is no obvious lateral boundary in glacier flow.

Total accumulation is integrated over each drainage basin using two digital maps of accumulation: (1) Giovinetto and Zwally (2000) and (2) Vaughan and others (1999). Table 2 shows the average of the two maps and the standard deviation. The standard deviation indicates the level of reliability of the balance flux, $\phi_{\mathrm{A}}$, in various sectors. Values are quoted in $\mathrm{km}^{3}$ ice $\mathrm{a}^{-1}$ using an ice density of $917 \mathrm{~kg} \mathrm{~m}^{-3}$. As noted above, wider or narrower flux gates could change $\phi_{\mathrm{A}}$ by $10-20 \%$ on some glaciers.

\section{InSAR products}

InSAR topography is generated from pairs of interferograms acquired along the same track, with appropriately long baselines. Control points are selected from the ERS DEM over a portion of the processed imagery that covers the ice-sheet interior. A measure of the quality of the InSAR topography is the degree of fit of the control elevations with the interferometrically derived elevations. The results vary from one glacier to the next, depending on the type of interferometric baselines available. In general, the precision is of a few tens of meters vertical (Figs 2-9).

Ice velocity is measured interferometrically combining ascending and descending passes to obtain a vector measurement of ice velocity (Joughin and others, 1998). This technique has an inherent precision of a couple of meters per year, in practice better than $10 \mathrm{~m} \mathrm{a}^{-1}$. The precision is greatest when InSAR topography is used to remove the topographic signal from the interferograms, which is done here on most glaciers.

Few areas were covered by ERS ascending passes in East Antarctica (Table 1), and most descending passes observed the glaciers in a direction perpendicular to ice flow, which is least favorable for InSAR mapping. To complete the InSAR measurements, a speckle-tracking technique (Michel and Rignot, 1999) was applied in the along-track direction of
ERS. The nominal precision of this technique is $1 / 30$ of a pixel (which is $4 \mathrm{~m}$ long along-track), hence a precision in velocity of $50 \mathrm{~m} \mathrm{a}^{-1}$ with 1 day repeat-pass data. This level of precision is acceptable for fast-moving glaciers.

The precision of speckle tracking improves to a few meters per year with RSAT data collected on a 24 day repeat-pass cycle with a $5 \mathrm{~m}$ pixel size (Joughin and others, 1999). Few 24 day interferometry passes were collected in 1997. More passes collected in late 2000 will be analyzed in the future.

Grounding-line positions are mapped using differential ERS InSAR, after removal of the topographic signal (Rignot, 1996). In the extreme case of the deeply entrenched David Glacier, an InSAR topographic map had to be generated from an adjacent track and removed from the differential InSAR before the grounding line could be made visible (Schmeltz and others, 2002).

The grounding-line flux gate was placed downstream of the limit of tidal flexing of the glaciers, at the outer boundary of the first fringe of tidal displacement. Earlier studies indicate that this position is closest to the line of first hydrostatic equilibrium of the ice (Rignot and others, in press) and also least contaminated by tidal motion.

The steady-state basal melt rate of the ice shelves, $\dot{B}$, is deduced from the grounding-line flux, $\phi_{\mathrm{GL}}$, reported in Table 2 and the flux estimated across the gate located downstream of the grounding line, $\phi_{\mathrm{BM}}$, using conservation of mass as

$$
\dot{B}=\frac{\phi_{\mathrm{BM}}-\phi_{\mathrm{GL}}-\delta \phi_{\mathrm{A}}}{\delta A},
$$

where $\delta \phi_{\mathrm{A}}$ and $\delta A$ are, respectively, snow accumulation and ice-shelf area in between the two gates. The gate for $\phi_{\mathrm{BM}}$ is located within 10-30 km of the grounding line. Prior results in North Greenland show that basal melting is highest in the deepest part of the cavity, within the first $10-20 \mathrm{~km}$ of floating ice, and decreases downstream to eventually reach negative values (Rignot, 1996). This melt pattern is broadly consistent with model predictions of basal melting (Hellmer and Olbers, 1989) and field experiments conducted on large ice shelves (Jenkins and Doake, 1991).

The downstream flux gates used here reach a compromise between measurement accuracy (the difference in flux needs to be large enough compared to the precision in ice flux), distance from the grounding line (melt rates are larger near the grounding zone) and quality of topographic mapping (topography is less reliable near the ice front). The emphasis is placed on estimating an average melt rate as close as possible to the g rounding line. A more detailed analysis of spatial variations in melt rate will be pursued in the future.

\section{RESULTS}

The estimates of grounding-line flux, $\phi_{\mathrm{GL}}$, balance flux, $\phi_{\mathrm{A}}$, and steady-state basal melt rate, $\dot{B}$, are listed in Tables 2 and 3 for each glacier, along with ice thickness and velocity at the grounding-line center, and size of the drainage basin. Each glacier is now discussed in more detail, starting from the Ross Sea and moving west toward the Weddell Sea.

\section{David Glacier}

This glacier develops into the $80 \mathrm{~km}$ long Drygalski Ice Tongue, Victoria Land. Several glaciological studies of this sector were reported by Frezzotti (1993) and Frezzotti and 

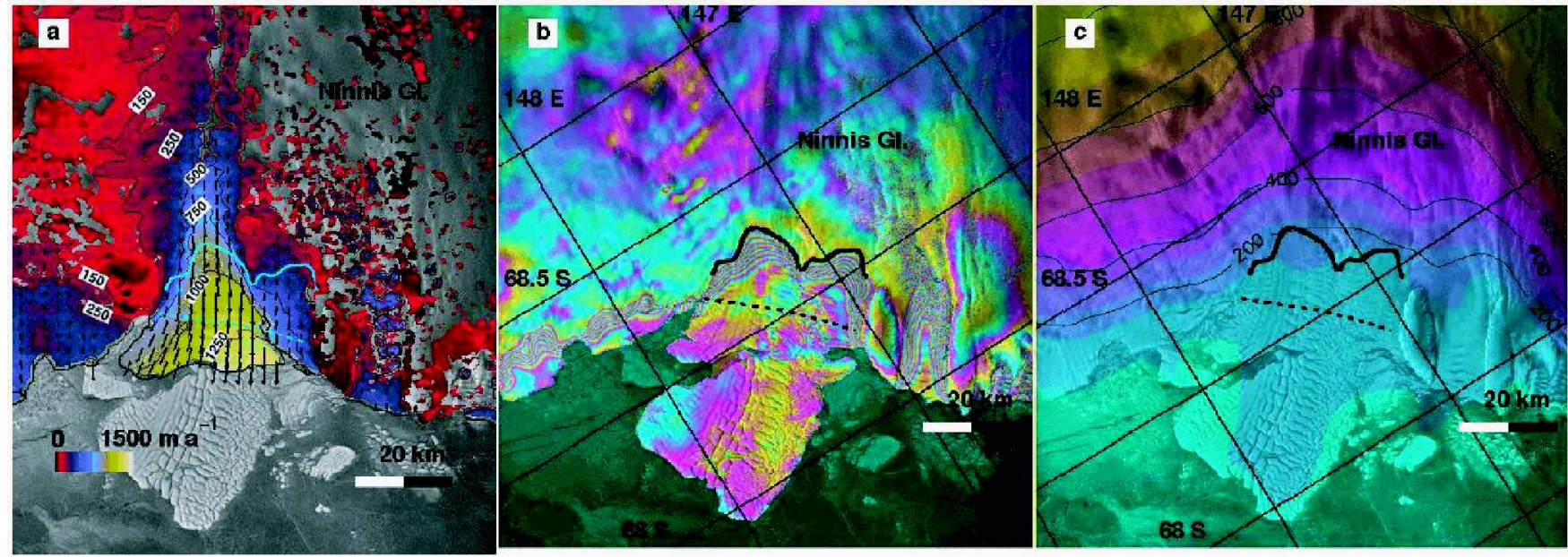

Fig. 3. Ninnis Glacier, Wilkes Land: ( a) velocity map from ERS; ( b) grounding-line position from ERS; and (c) topography from radar altimetry. See Figure 2 for legend.

others (2000). The grounding line, initially placed at the mouth of the glacier bay between Hughes Bluff and Mount Neumayer (Frezzotti, 1993), was subsequently revised further upstream, at the mouth of David Cauldron (Frezzotti and others, 2000), at the southern limit of a global positioning system (GPS) survey of the ice tongue.

InSAR indicates the grounding-line position is located $15 \mathrm{~km}$ upstream of the GPS survey (Fig. 2), at the foot of an icefall (Fig. 2b). The icefall, spectacular from the air (Swithinbank, 1988), is caused by a subglacial ridge that cuts across the glacier. Below the icefall, the glacier plunges into a deep fjord-like valley, revealed by an abrupt distortion of flowlines. The flow speed is $500 \mathrm{~m} \mathrm{a}^{-1}$ at the grounding line (Fig. 2a). The glacier thickness reaches a maximum $3400 \mathrm{~m}$ at the grounding-line center based on the radar altimetry DEM (Fig. 2d). The average grounding-line thickness across the flux gate is $1900 \pm 200 \mathrm{~m}$. The InSAR-derived topography (Fig. 2c) suggests a lower maximum thickness of $2900 \mathrm{~m}$, yet InSAR-derived topography is less reliable at that location because of data loss from intense crevassing of the ice.

The maximum grounding-line thickness estimated here is twice that reported by Frezzotti and others (2000), yet no radar echoes were successfully measured within $15 \mathrm{~km}$ of the InSAR-derived grounding line (personal communication from M. Frezzotti, 2000). This result illustrates the difficulty of ice radar sounding in severely crevassed sectors of thick ice. Steed and Drewry (1982) found that the glacier coincides with a deep subglacial trench that transects the whole coastal mountain range and extends inland for $>300 \mathrm{~km}$. The only measurement of ice thickness in that sector is a radar sounding of $2530 \mathrm{~m}$ reported by Swithinbank (1988) above the icefall, on the flanks of the fast-flowing portion of David Glacier, therefore away from the deepest part of the subglacial trench. This measurement supports the presence of much thicker ice in the center of the subglacial trench.

Ice velocity was measured in vector form using ERS ascending and descending tracks (Table 1). The groundingline flux of $15.4 \mathrm{~km}^{3}$ ice $\mathrm{a}^{-1}$ agrees with a mass accumulation of $16.4 \pm 4 \mathrm{~km}^{3}$ ice $\mathrm{a}^{-1}$. The two accumulation maps, however, differ by $24 \%$ in that sector. The drainage shown in Figure 1 includes Dome C, whereas Frezzotti and others (2000) obtained a different result with a different DEM. In addition, Frezzotti and others (2000) questioned the validity of existing accumulation maps in this sector in light of recent ice-core data. There are therefore uncertainties in the balance flux of this glacier. The present analysis, however, suggests conditions close to a state of mass balance $\left(+1 \pm 4 \mathrm{~km}^{3}\right.$ ice $\left.\mathrm{a}^{-1}\right)$.

Basal melting between the grounding-line position of Frezzotti and others (2000) and the InSAR grounding line is $29 \pm 6 \mathrm{mice} \mathrm{a}^{-1}$ (Table 3). Further downstream, basal melting decreases by a factor of two (not shown in Table 3), which is consistent with the melt rate of $16 \pm 6 \mathrm{~m}^{\text {ice }} \mathrm{a}^{-1}$ estimated by Frezzotti and others (2000) combining radarsounding ice thickness with GPS velocities in the same area. As expected, basal melting is highest near the grounding zone and decreases downstream.

\section{Ninnis and Mertz Glaciers}

These two neighboring glaciers drain from the flanks of Dome C, but do not reach the dome (Fig. 1). Mertz Glacier Tongue (Fig. 3) extends $95 \mathrm{~km}$ into the ocean and is reported to be at its glacial maximum. Ninnis Glacier Tongue (Fig. 4) has retreated steadily since 1912 (Wendler and others, 1996), and underwent a major calving event in 2000 which removed half of the floating tongue (personal communication from M. Frezzotti, 2001). Ninnis Glacier drains a larger sector than Mertz Glacier, with comparable discharge velocities but lower accumulation (Table 2). Both glaciers flow nearly parallel to the satellite track direction (no ascending track exists in this sector). A comparison of ice discharge with mass accumulation suggests conditions close to a state of mass balance (Table 2): $+3 \pm 3 \mathrm{~km}^{3}$ ice $\mathrm{a}^{-1}$ for Ninnis Glacier and $+1.5 \pm 3 \mathrm{~km}^{3}$ ice $\mathrm{a}^{-1}$ for Mertz Glacier.

Basal melting is larger on Mertz Glacier Tongue than on Ninnis Glacier Tongue under steady-state conditions (Table 3). Given the significant retreat of Ninnis ice front since early in the 20th century, it is possible that Ninnis Glacier Tongue is thinning at present, in which case conservation of mass dictates that basal melting would be higher than calculated here. The difference in bottom melt rate between the two glaciers, which are similar in thickness and size, could also express local differences in ocean forcing. No significant shift in ocean temperature or salinity is expected between the two areas, but the sub-ice-shelf cavities are different: the grounding line of Mertz Glacier expands $>50 \mathrm{~km}$ inland from the coast, compared to only a few $\mathrm{km}$ in the case of Ninnis 

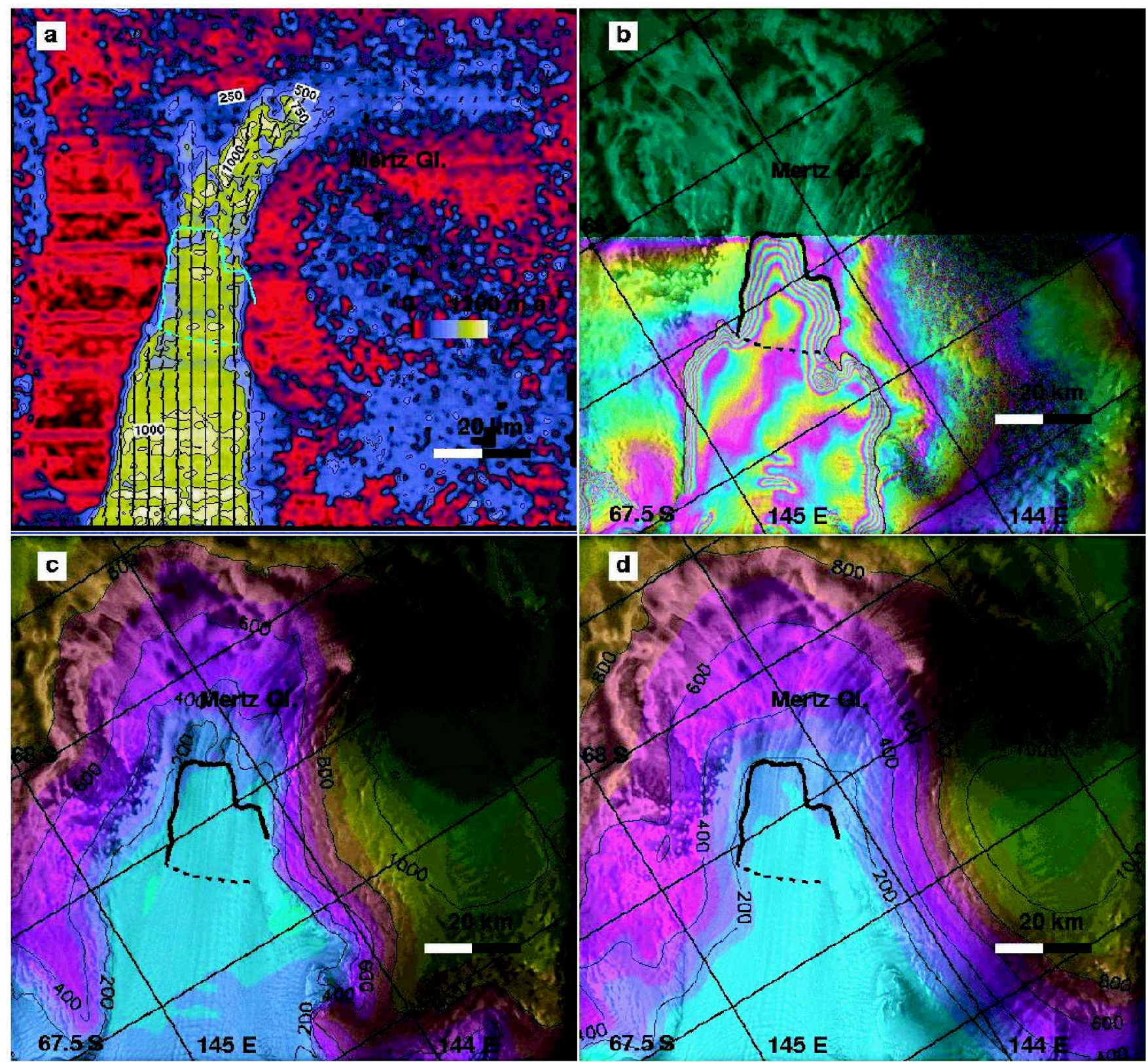

Fig. 4. Mertz Glacier,Wilkes Land: ( a) velocity map from ERS; (b) grounding-line position from ERS; topography from (c) ERS InSAR and (d) ERS radar altimetry. See Figure 2 for legend.

Glacier. The deeply entrenched grounding line of Mertz Glacier may favor higher rates of basal melting.

\section{Totten Glacier}

Totten Glacier is the largest discharger of ice in East Antarctica. Fast flow is concentrated along the flanks of Law Dome. Ice velocity reaches $900 \mathrm{~m} \mathrm{a}^{-1}$ at the grounding line, with an ice thickness of about $2100 \mathrm{~m}$ (Fig. 5a and c). The western side of the glacier, nearly $100 \mathrm{~km}$ wide, drains a vast sector of the ice sheet, at about $300 \mathrm{~m} \mathrm{a}^{-1}$, approximately perpendicular to the coastline.

The grounding line of the fast-moving part of the glacier is located $>130 \mathrm{~km}$ inland from the ice front (Fig. 5b). InSAR reveals the presence of a large area of grounded ice, about $15 \mathrm{~km}$ wide, near the glacier center. This grounded area is not an ice rise since ice velocity does not decrease to zero at the center and the feature is not visible in satellite imagery. Its flexure zone, however, experiences the full range of tidal displacement (the same number of fringes are counted across it as across the flexure zone of the main trunk of Totten Glacier), hence it is grounded at all times. This feature corresponds to an ice rumple.

Another particularity of the glacier is the extension of the southernmost sector of the grounding line along two finger-shaped branches. The InSAR signal recorded in this area does not extend to the full amplitude of tidal flexing, which suggests that it is only grounded at low tide. This behavior must be due to shallow bed slopes and intrusion of ocean water at the glacier underside during high tide.

Determining the most relevant flux gate for this glacier is not straightforward because of its vast, slow-moving, nearly featureless, western front. The flux gate was selected based on the grounding-line geometry and the presence of neighboring glaciers and domes. The corresponding ice flux, $69.9 \pm 7 \mathrm{~km}^{3}$ ice $\mathrm{a}^{-1}$, is the largest of any glacier considered here, but is close to a mass accumulation of $68.8 \pm 10$ $\mathrm{km}^{3}$ ice $\mathrm{a}^{-1}$ (Table 2). Basal melting in the proximity of the grounding line averages $20 \pm 9 \mathrm{~m} \mathrm{a}^{-1}$ (Table 3). 

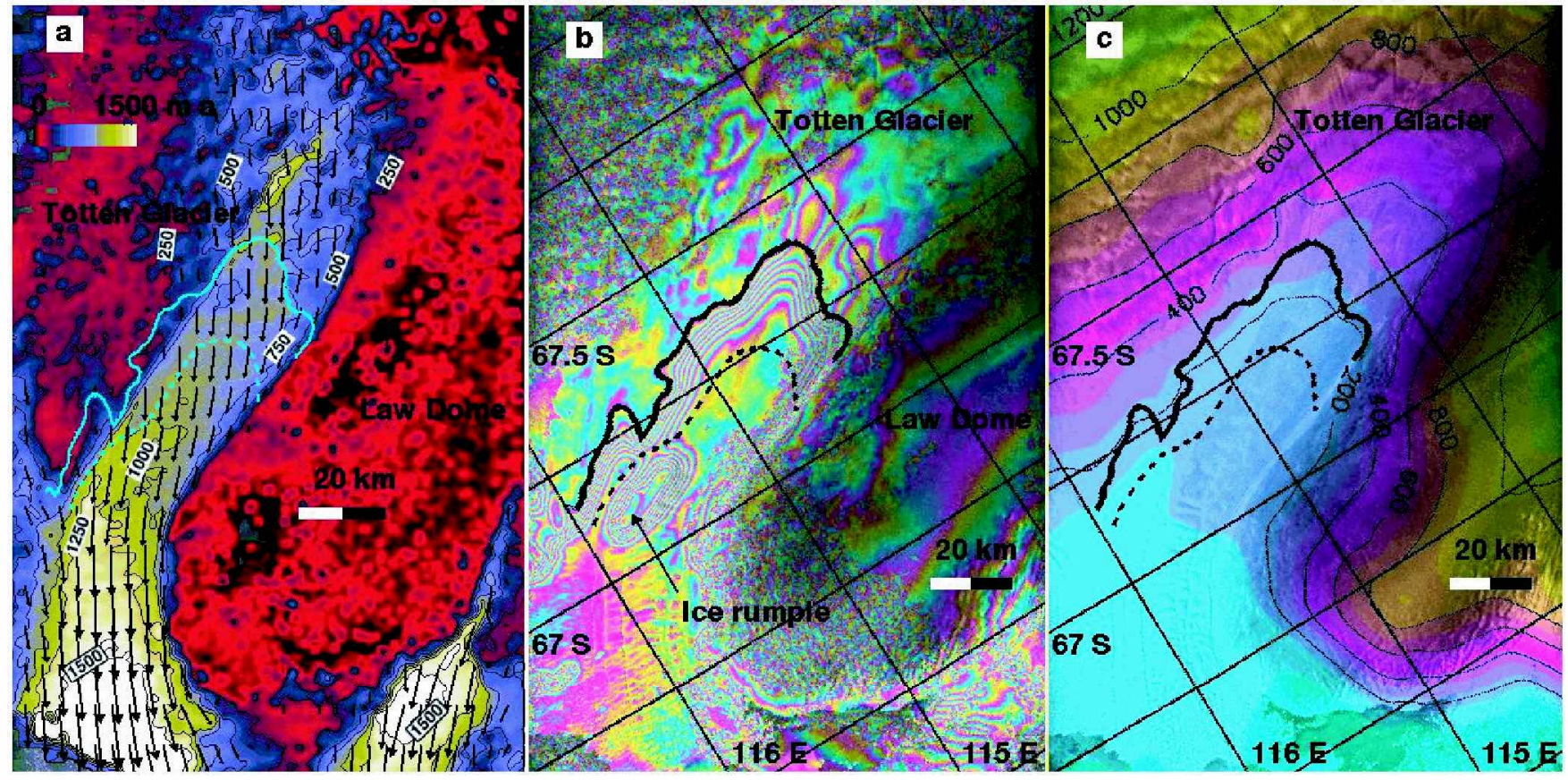

Fig. 5. Totten Glacier, Wilkes Land: (a) velocity map from ERS; (b) grounding-line position from ERS; and (c) topography from ERS radar altimetry. See Figure 2 for legend.

\section{Denman and Scott Glaciers}

Prominent flowlines are visible on Denman Glacier for several hundred $\mathrm{km}$ inland (Fig. 6). The glacier flows at about $1500 \mathrm{~m} \mathrm{a}^{-1}$ at the grounding line, where it splits into two branches, before punching through Shackleton Ice Shelf, almost undisturbed. The InSAR grounding line (Fig. $6 \mathrm{~b}$ ) is found several $\mathrm{km}$ upstream of the position inferred by Swithinbank (1988) from Landsat imagery. The groundingline flux of $35.1 \pm 5 \mathrm{~km}^{3}$ ice $\mathrm{a}^{-1}$ is $2.5 \pm 10 \mathrm{~km}^{3}$ ice $\mathrm{a}^{-1}$ less than the calculated balance discharge. The uncertainty in snow accumulation is $9 \mathrm{~km}^{3} \mathrm{a}^{-1}$ in this sector. It is therefore difficult to determine the state of mass balance of this glacier. Scott Glacier, to the east of Denman Glacier, flows at $500 \mathrm{~m} \mathrm{a}^{-1}$ at the grounding line, and discharges $9.2 \pm 2 \mathrm{~km}^{3}$ ice $\mathrm{a}^{-1}$. It is therefore much less active than Denman Glacier. Basal melting estimated over the main trunk of Denman Glacier (Table 3 ) is large. The inferred rates are lower on Scott Glacier, which is thinner.

\section{Lambert Glacier}

The grounding-line position of Lambert, Mellor and Fisher Glaciers has been subject to controversy. Hambrey and Dowdeswell (1994) argued that the grounding-line position of Budd and others (1982), subsequently used in many other studies, was inconsistent with glaciological features visible in Landsat imagery in the upstream area, and that the true
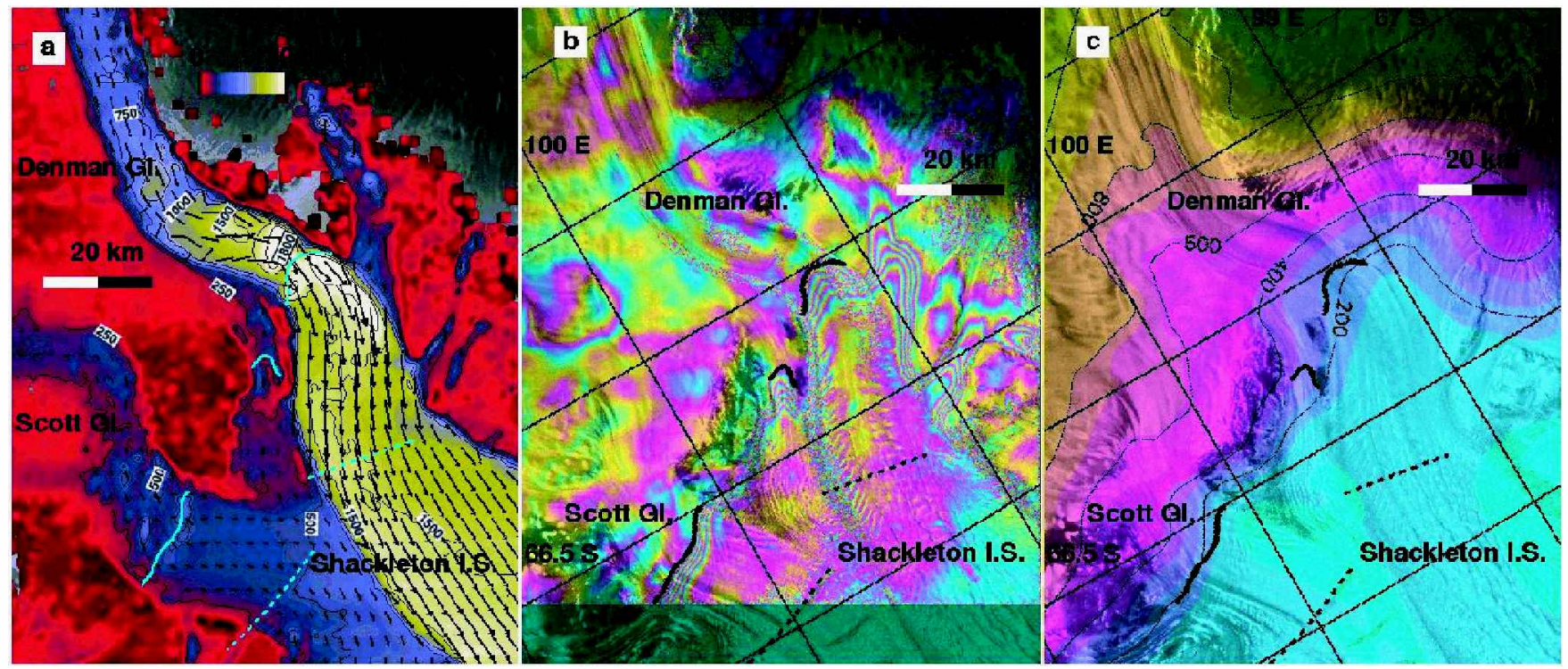

Fig. 6. Denman and Scott Glaciers, Wilkes Land: (a) velocity mapfrom ERS; (b) grounding-line position from ERS; and (c)

topography from ERS radar altimetry. See Figure 2 for legend. 


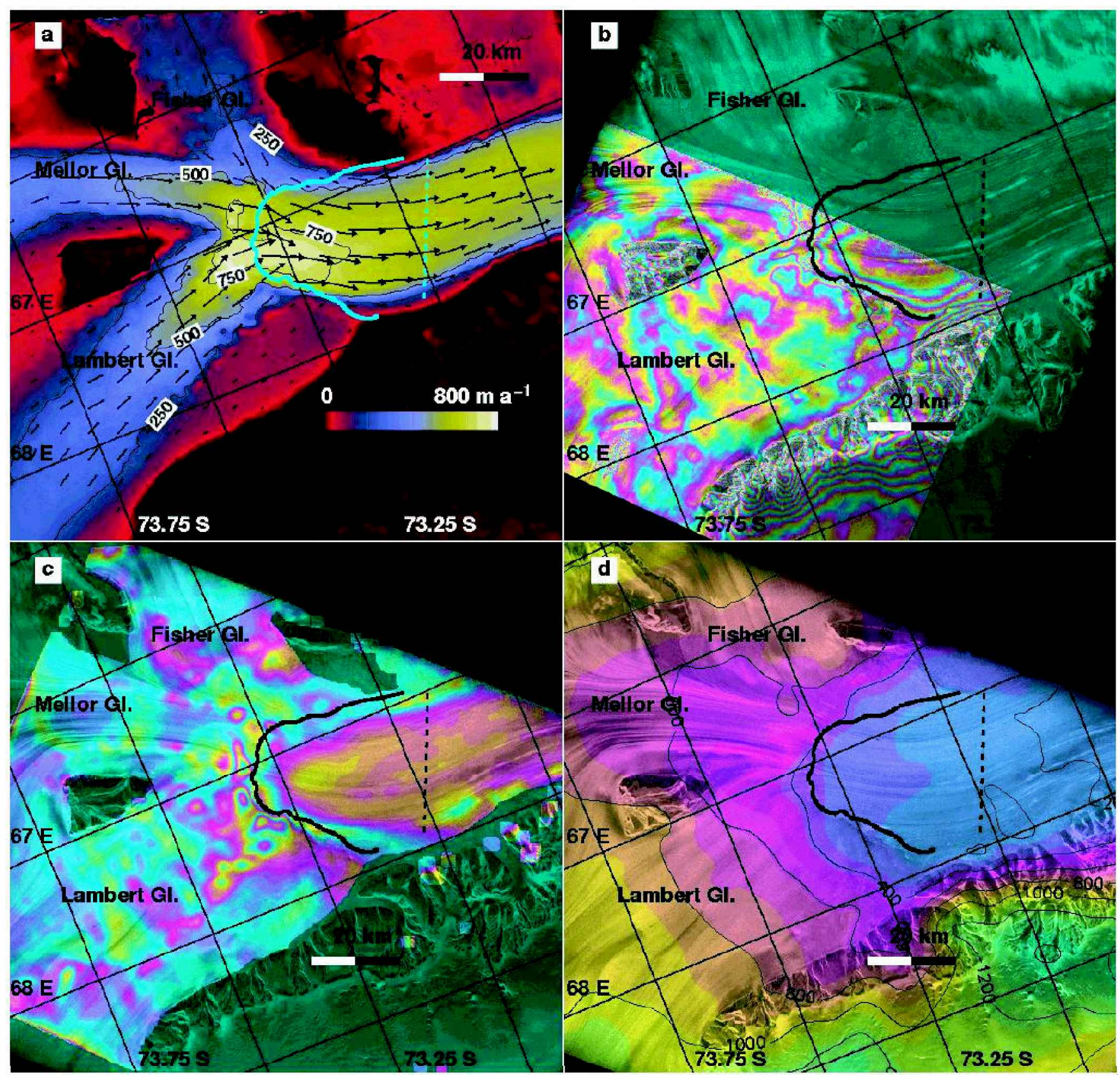

Fig. 7. Lambert, Fisher and Mellor Glaciers, American Highland: ( a) velocity map from RSAT; ( $b$ ) grounding-line position from ERS; (c) difference in ice velocity between ERS three-dimensional InSAR and RSAT speckle tracking (each color cycle represents a $200 \mathrm{~m} \mathrm{a}^{-1}$ difference in ice velocity, which is largest on floating ice); and (d) topography from ERS radar altimetry. See Figure 2 for legend.

grounding line ought to be located much further south. Fricker and others (2000) showed that the grounding-line position was located some $200 \mathrm{~km}$ upstream, based on hydrostatic equilibrium. Their analysis, however, could not locate the groundingline position better than within several $\mathrm{km}$.

InSAR confirms Fricker and others' (2000) interpretation of a grounding-line location much further south (Fig. 7). Only half of the grounding line of the Lambert/Mellor/Fisher system could be mapped with precision due to a lack of multiple InSAR coverage on Mellor and Fisher Glaciers. Grounding-line mapping was extended beyond the range provided by differential InSAR using other clues: (1) the topographic map of the ice shelf; (2) the boundary of narrow fringes (i.e. tidal flexure combined with horizontal strain) visible along the slow-moving western flank of the ice shelf; and (3) a map of the difference in ice velocity between ERS
InSAR, which is contaminated by oceanic tides on the shelf, and RADARSAT speckle tracking, which has negligible contamination from oceanic tides (Fig. 7c). The resulting precision of grounding-line mapping is $100 \mathrm{~m}$ for Lambert Glacier and $300 \mathrm{~m}$ for Mellor and Fisher Glaciers. Ice thickness is estimated to be reliable to within $\pm 200 \mathrm{~m}$.

Ice velocity is $800 \mathrm{~m} \mathrm{a}^{-1}$ at the grounding line. Ice thickness is $3000 \mathrm{~m}$ at the glacier center, based on hydrostatic equilibrium (Table 2). The combined grounding-line flux from Lambert, Mellor and Fisher Glaciers calculated from ERS vector mapping(ascending and descending tracks) and the grounding-line flux from RSAT 24 day speckle tracking differ only by $0.6 \mathrm{~km}^{3} \mathrm{a}^{-1}$ or $1 \%$. The groundingline flux obtained using RSAT data, $57.5 \pm 5 \mathrm{~km}^{3}$ ice $\mathrm{a}^{-1}$, exceeds the calculated mass input of $55.2 \pm 1 \mathrm{~km}^{3}$ ice $\mathrm{a}^{-1}$ by $4 \pm 9 \%$, which suggests a glacier system close to balance. 

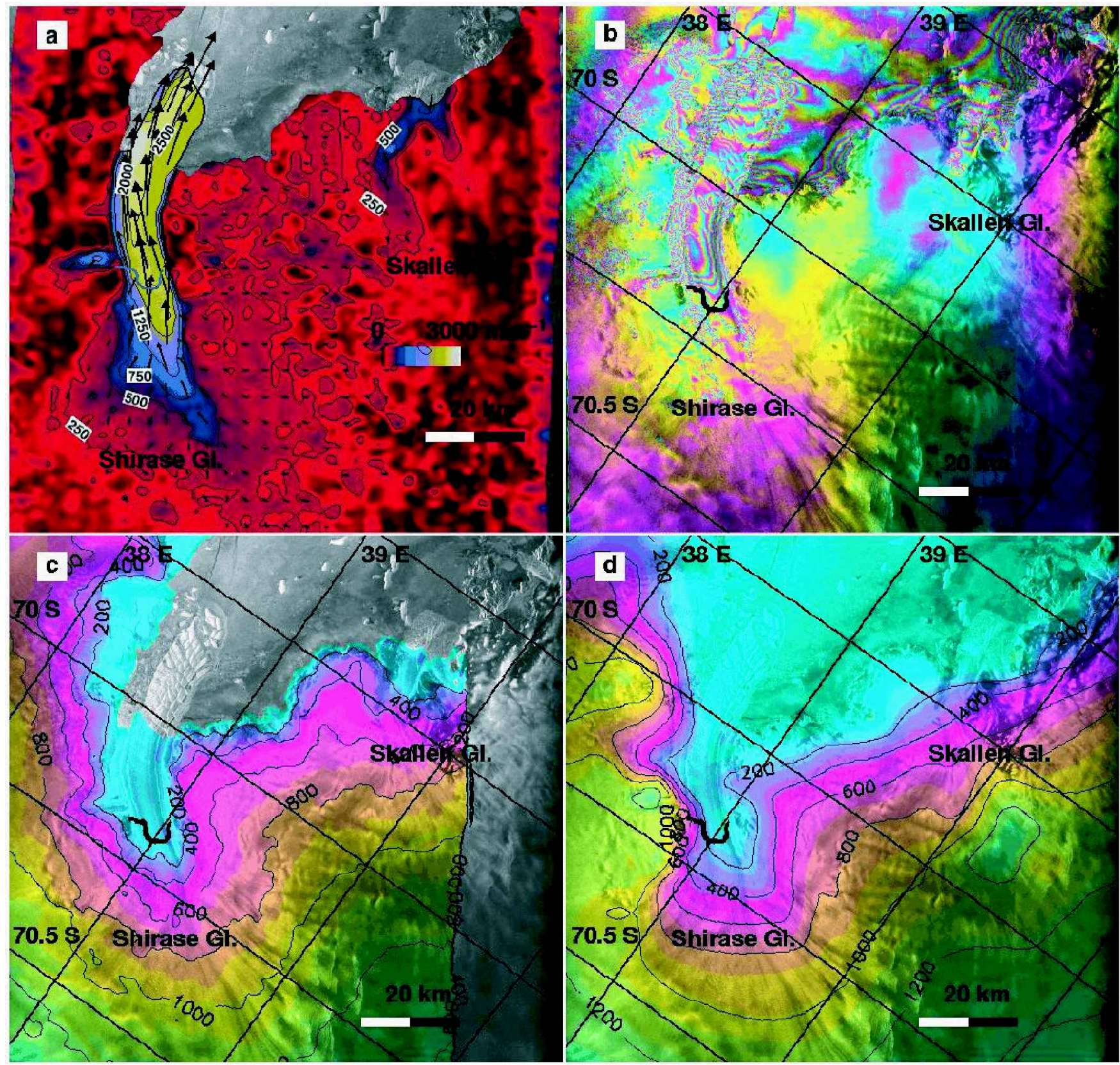

Fig. 8. Shirase Glacier, Enderby Land: ( a) velocity map from ERS; (b) grounding-line position from ERS; topography from (c) ERS InSAR and (d) ERS radar altimetry. See Figure 2 for legend.

The drainage basin of Lambert Glacier is therefore almost certainly not thickening rapidly, and perhaps even thinning.

Basal melting in the vicinity of the grounding line exceeds $32 \pm 5 \mathrm{~m}$ ice $\mathrm{a}^{-1}$ (Table 3). With a flux gate located near the outer edge of the scene in Figure $7, \dot{B}$ decreases to $26 \mathrm{~m}$ ice $^{-1}$ over an ice-shelf area of $1330 \mathrm{~km}^{2}$. More than half the glacier thickness melts in the first $1000 \mathrm{~km}^{2}$ ice-shelf area. The high value of basal melting recorded near the grounding zone explains why prior estimates of the glacier system mass balance determined massive thickening in this sector (Allison, 1979). Mass losses between the new and old grounding lines were not accounted for in prior estimations of the mass budget of this glacier system.

\section{Shirase Glacier}

This glacier flows down a narrow trench at $2400 \mathrm{~m} \mathrm{a}^{-1}$ near the grounding line and $3000 \mathrm{~m} \mathrm{a}^{-1}$ on the floating tongue. Skallen Glacier, east of Shirase Glacier, flows at $500 \mathrm{ma}^{-1}$
(Fig. 8). The ERS DEM is unreliable near the grounding line of Shirase Glacier and on the ice shelf, as can be judged from the InSAR altimetry comparison in Figure $8 c$ and d. Using InSAR topography, ice thickness at the grounding line, about $900 \mathrm{~m}$, was estimated with a precision no better than $200 \mathrm{~m}$. Combined with a $10 \mathrm{ma}^{-1}$ uncertainty in ice velocity, this yields a precision in mass flux of $22 \%$. The glacier mass discharge of $15.1 \pm 3 \mathrm{~km}^{3}$ ice $\mathrm{a}^{-1}$ is only $1.8 \pm 3 \mathrm{~km}^{3}$ ice $\mathrm{a}^{-1}$ lower than the calculated balance flux, which suggests conditions close to mass balance.

Basal melting is difficult to estimate on the ice shelf due to a lack of quality thickness data or ice-shelf elevation (the InSAR topography is contaminated by oceanic tides).

\section{Stancomb-Wills Glacier}

This glacier flows at $700 \mathrm{~m} \mathrm{a}^{-1}$ near its grounding line, and accelerates to $>1200 \mathrm{~m} \mathrm{a}^{-1}$ on its fan-shaped ice tongue (Table 2; Fig. 9). The floating tongue experiences little shear along its 

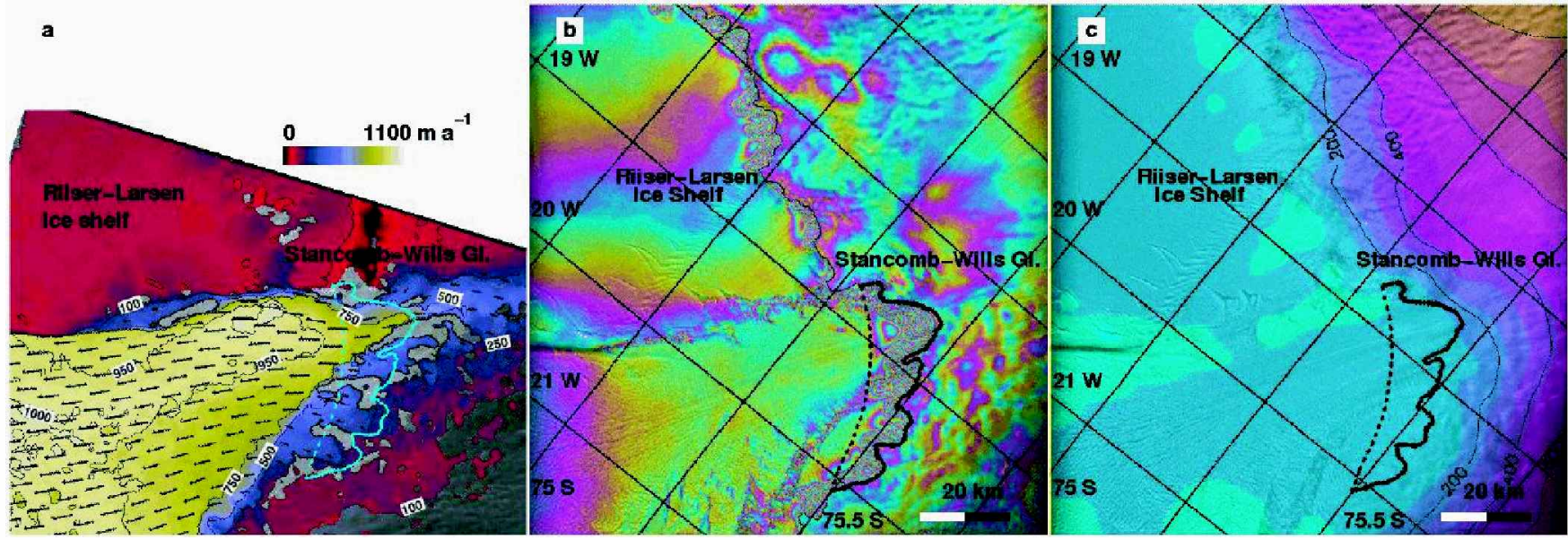

Fig. 9. Stancomb-Wills Glacier, Coats Land: (a) velocity map from RSAT; (b) grounding-line position from ERS; and (c) topography from ERS radar altimetry. See Figure 2 for legend.

sides according to the InSAR data, so it is practically unconfined. The neighboring Riiser-Larsen Ice Shelf is nearly stagnant. The estimated mass flux of Stancomb-Wills Glacier, $16.6 \pm 2 \mathrm{~km}^{3}$ ice $\mathrm{a}^{-1}$, is 3 times less than in Swithinbank (1988), but in reasonable agreement (the mass balance is $0.9 \pm 3 \mathrm{~km}^{3}$ ice $\mathrm{a}^{-1}$ ) with mass accumulation in the interior.

The inferred rate of basal melting is low near the grounding line, only $4 \pm 8 \mathrm{~m} \mathrm{a}^{-1}$. With the flux gate located even further downstream, over an ice-shelf area twice the one considered in Table 3, a similar calculation shows basal freezing of a few meters per year (not shown in Table 3). Basal melting is therefore much less efficient in that sector compared to other glaciers, and the ice tongue as a whole is in fact likely dominated by basal freezing.

Stancomb-Wills Glacier Tongue is glued together by an ice melange (Rignot and MacAyeal, 1998), probably composed of blown snow, sea ice and broken icebergs, which is mechanically competent (the InSAR deformation field is nearly continuous across the boundaries between ice tongue and melange), hence thick enough to transmit stresses. The slight bend in fringes observed across transition boundaries between ice tongue and ice melange decreases downstream from the grounding line, which indicates that the thickness of the ice melange increases with time. This evolution pattern is consistent with bottom freezing.

\section{DISGUSSION AND GONGLUSIONS}

This study provides a major revision of grounding-line positions in East Antarctica. This mapping exercise is a unique contribution of the ERS tandem mission. It should serve as a reference for measuring future grounding-line migration of Antarctic glaciers. The detection of grounding-line migration is a powerful way to estimate local mass balance, independent of snow accumulation and bottom melting (Rignot, 1998).

In several sectors (e.g. David and Lambert Glaciers), the grounding line is detected several tens of $\mathrm{km}$ inland of its prior-determined position. This mislocation has major consequences for the estimation of the mass budget of the glaciers: those glaciers are not massively thickening at present, and snow accumulation over the drainage basins is not unreasonably represented in existing digital maps. Most glaciers considered in this study in fact appear reasonably close to mass equilibrium.
The last row of Table 2 totals the contribution from all glaciers. Total mass discharge is $260.5 \pm 11 \mathrm{~km}^{3}$ ice $\mathrm{a}^{-1}$, which is $7 \pm 19 \mathrm{~km}^{3}$ ice $\mathrm{a}^{-1}(3 \pm 7 \%)$ less than the total balance discharge of $267.4 \pm 15 \mathrm{~km}^{3}$ ice $\mathrm{a}^{-1}$. The nine glaciers together drain about one-quarter of East Antarctica's grounded ice. The result therefore suggests that there is no large mass imbalance in the sector of East Antarctica that does not drain into the Ross and Filchner-Ronne Ice Shelves. For comparison, a similar mass-budget approach applied to West Antarctic glaciers (Fig. 1) reveals a strongly negative mass balance in the Amundsen Sea sector (Rignot, 2001; Rignot and others, 2002). From these results we may conclude that the apparent contribution of East Antarctic glaciers to sealevel rise is negligible at present. The only significant contribution from the Antarctic ice sheet (i.e. excluding the peninsula) is in the Amundsen Sea sector of West Antarctica.

To improve upon the estimates of mass balance presented here, better ice-thickness estimates are needed along all grounding zones. Upcoming satellite missions will improve the determination of the geoid and the precision of ice-shelf elevations, yet direct measurements of ice thickness would be preferable to improve the precision of mass fluxes.

Basal melting was estimated assuming steady-state conditions, which are not known for certain. Conservation of mass dictates that if the ice shelves are thinning, then basal melting is larger than calculated here. Conversely, basal melting is overestimated if the ice shelves are gaining mass. Information on the rate of ice-shelf thickness change is now becoming available from ERS radar altimetry (personal communication from H.J. Zwally, 2001). Ice shelves along the West Antarctic coast thin by $20-60 \mathrm{~cm} \mathrm{a}^{-1}$, which implies a thinning of $1-4 \mathrm{mice}^{-1}$. These thinning rates are large compared to those recorded on large ice shelves (nearly zero), but small compared to the basal melt rates listed in Table 3.

Basal melt rates reach a few meters per year near the grounding zones of the glaciers draining into the Ross, Ronne and Filchner Ice Shelves (e.g. Jenkins and Doake, 1991), but the average melt rate of those large ice shelves is only about $20 \mathrm{~cm}$ ice $\mathrm{a}^{-1}$. In North Greenland, basal melt rates reach $25 \mathrm{~m} \mathrm{a}^{-1}$ within $10 \mathrm{~km}$ of the grounding zones and average $5-8 \mathrm{~m} \mathrm{a}^{-1}$ over the entire floating area (Rignot, 1996; Rignot and others, 1997, in press). This study shows that similarly high values are encountered in the Antarctic, where ice shelves are more widespread than in Greenland. Basal melting averages $24 \pm 7 \mathrm{~m}$ ice $\mathrm{a}^{-1}$ in Table 3, except 
for two glaciers where $\dot{B}$ averages $4 \pm 7 \mathrm{~m}$ ice $\mathrm{a}^{-1}$. The fact that basal melting tends to be higher in the Antarctic than in North Greenland is consistent with the deeper draft of Antarctic glaciers (the thickness of grounding zones of major North Greenland glaciers is $600 \mathrm{~m}$ vs $900-3000 \mathrm{~m}$ in the Antarctic). Ice reaching greater depths is more likely to melt due to the pressure dependence of the melting point of ice. Even higher melt rates have been inferred in Pine Island Bay (Jacobs and others, 1996; Rignot, 1998, 2001).

The detection of low rates of basal melting in some regions requires further investigation. The result suggests that basal melting does not simply scale with ice thickness. One striking common feature of low bottom-melt producers such as Ninnis and Stancomb-Wills Glaciers is that their grounding line is located close to the coast. Glaciers with a grounding line located deep inland of the coastline therefore tend to experience higher rates of bottom melting than those with a grounding line located near the coast. Coastal geometry could be an important control on the efficiency of bottom melting, which should be investigated in future studies.

One consequence of the importance of basal melt processes in the Antarctic is that iceberg calving may not be the dominant term of mass attrition on floating ice (Jacobs and others, 1992). A revision of basal melt estimates to higher values would imply a more negative mass balance of Antarctic ice.

Another consequence is that Antarctic glaciers are more sensitive to changes in ocean conditions than presumed earlier (e.g. based on studies of bottom melting underneath large ice shelves). Warner and Budd (1998) and Huybrechts and de Wolde (1999) showed that enhanced basal melting is an efficient way to collapse an ice sheet. The magnitude of basal melting used in their simulations was no more than a few $m$ ice $\mathrm{a}^{-1}$. The melt rates discussed here are one order of magnitude larger. It is not clear how ice-sheet models could maintain the ice sheet in a state of mass balance if they included the melt rates quoted here. While these models have their own limitations, this raises the question of the stability of Antarctic ice shelves in the present climate. Are ice shelves able to sustain those high rates of melting? Are ocean conditions leading to those high rates of melting changing at present? How do ice streams and glaciers react to changes in bottom melting? More extensive measurements of basal melting, using in situ and/or remote-sensing methods, would be timely.

\section{AGKNOWLEDGEMENTS}

This work was performed at the Jet Propulsion Laboratory, California Institute of Technology, under a contract with the National Aeronautics and Space Administration, Polar Program. The European Space Agency and the Canadian Space Agency are acknowledged for collecting and distributing the radar data employed in this study.

\section{REFERENGES}

Allison, I. 1979. The mass budget of the Lambert Glacier drainage basin, Antarctica. 7. Glaciol., 22(87), 223-235.

Bamber, J. L. and R. A. Bindschadler. 1997. An improved elevation dataset for climate and ice-sheet modelling: validation with satellite imagery. Ann. Glaciol., 25, 439-444.

Budd, W. F., M. J. Corry and T. H. Jacka. 1982. Results from the Amery Ice Shelf Project. Ann. Glaciol., 3, 36-41.

Frezzotti, M. 1993. Glaciological study in Terra Nova Bay, Antarctica, inferred from remote sensing analysis. Ann. Glaciol., 17, 63-71.
Frezzotti, M., I. E. Tabacco and A. Zirizzotti. 2000. Ice discharge of eastern Dome C drainage area, Antarctica, determined from airborne radar survey and satellite image analysis. f. Glaciol., 46(153), 253-264.

Fricker, H. A., G. Hyland, R. Coleman and N.W. Young. 2000. Digital elevation models for the Lambert Glacier-Amery Ice Shelf system, East Antarctica, from ERS-1 satellite radar altimetry. 7. Glaciol., 46(155), 553-560.

Giovinetto, M. B. and H. J. Zwally. 2000. Spatial distribution of net surface accumulation on the Antarctic ice sheet. Ann. Glaciol., 31, 171-178.

Hambrey, M. J. and J. A. Dowdeswell. 1994. Flow regime of the Lambert Glacier-Amery Ice Shelf system, Antarctica: structural evidence from Landsat imagery. Ann. Glaciol., 20, 401-406.

Hellmer, H. H. and D. J. Olbers. 1989. A two-dimensional model for the thermohaline circulation under an ice shelf. Antarct. Sci., 1 (4), 325-336.

Huybrechts, P. and J. de Wolde. 1999. The dynamic response of the Greenland and Antarctic ice sheets to multiple-century climatic warming. $\mathcal{F}$. Climate, 12(8), 2169-2188.

Jacobs, S. S., H. H. Hellmer, C. S. M. Doake, A. Jenkins and R.M. Frolich. 1992. Melting of ice shelves and the mass balance of Antarctica. F. Glaciol., 38(130), 375-387.

Jacobs, S. S., H. H. Hellmer and A. Jenkins. 1996. Antarctic ice sheet melting in the southeast Pacific. Geophys. Res. Lett., 23(9), 957-960.

Jenkins, A. and C. S. M. Doake. 1991. Ice-ocean interaction on Ronne Ice Shelf, Antarctica. f. Geophys. Res., 96(C1), 791-813.

Joughin, I. R., R. Kwok and M. A. Fahnestock. 1998. Interferometric estimation of three-dimensional ice-flow using ascending and descending passes. IEEE Trans. Geosci. Remote Sensing, GE-36(1), 25-37.

Joughin, I. and 7 others. 1999. Tributaries of West Antarctic ice streams revealed by RADARSAT interferometry. Science, 286(5438), 283-286.

Krabill, W. and 9 others. 2000. Greenland ice sheet: high-elevation balance and peripheral thinning. Science, 289(5478), 428-430.

Liu, H., K. C. Jezek and B. Li. 1999. Development of an Antarctic digital elevation model by integrating cartographic and remotely sensed data: a geographic information system based approach. 7. Geophys. Res., 104(B10), 23,199-23,213

Lythe, M. B., D. G. Vaughan and BEDMAP consortium. 2000. BEDMAPbed topography of the Antarctic. British Antarctic Survey. (BAS (Misc) 9, scale $1: 10,000,000$.)

Michel, R. and E. Rignot. 1999. Flow of Glaciar Moreno, Argentina, from repeat-pass Shuttle Imaging Radar images: comparison of the phase correlation method with radar interferometry. F. Glaciol., 45(149), 93-100.

Rignot, E. 1996. Tidal motion, ice velocity and melt rate of Petermann Gletscher, Greenland, measured from radar interferometry. F. Glaciol., 42(142), 476-485.

Rignot, E. J. 1998. Fast recession of a West Antarctic glacier. Science, $281(5376), 549-551$.

Rignot, E. 2001. Evidence for rapid retreat and mass loss of Thwaites Glacier, West Antarctica. F. Glaciol., 47(157), 213-222.

Rignot, E. and D. R. MacAyeal. 1998. Ice-shelf dynamics near the front of the Filchner-Ronne Ice Shelf, Antarctica, revealed by SAR interferometry. F. Glaciol., 44(147), 405-418.

Rignot, E. J., S. P. Gogineni, W. B. Krabill and S. Ekholm. 1997. North and north-east Greenland ice discharge from satellite radar interferometry. Science, 276(5314), 934-937.

Rignot, E., D. G. Vaughan, M. Schmeltz, T. Dupont and D. MacAyeal. 2002. Acceleration of Pine Island and Thwaites Glaciers, West Antarctic. Ann. Glaciol., 34 (see paper in this volume).

Rignot, E., W. B. Krabill, S. P. Gogineni and I. Joughin. In press. Contribution to the glaciology of northern Greenland from satellite radar interferometry. 7. Geophys. Res.

Schmeltz, M., E. Rignot and D. MacAyeal. 2002. Tidal flexure zones along ice-sheet margins: comparison of InSAR with an elastic plate model. Ann. Glaciol., 34 (see paper in this volume).

Steed, R. H. N. and D. J. Drewry. 1982. Radio-echo sounding investigation of Wilkes Land, Antarctica. In Craddock, C., ed. Antarctic geoscience. Madison, WI, University of Wisconsin Press, 969-975.

Swithinbank, C. 1988. Antarctica, with sections on the "Dry Valleys" of Victoria Land, by T. J. Chinn, and Landsat images of Antarctica by R. S. Williams, Jr and J. Ferrigno. U.S. Geol. Surv. Prof. Pap. 1386-B.

Vaughan, D. G., J. L. Bamber, M. B. Giovinetto, J. Russell and A. P. R. Cooper. 1999. Reassessment of net surface mass balance in Antarctica. 7. Climate, 12(4), 933-946.

Warner, R. C. and W. F. Budd. 1998. Modelling the long-term response of the Antarctic ice sheet to global warming. Ann. Glaciol., 27, 161-168.

Wendler, G., K. Ahlnäs and C. S. Lingle. 1996. On Mertz and Ninnis Glaciers, East Antarctica. 7. Glaciol., 42(142), 447-453.

Wingham, D. J., A. L. Ridout, R. Scharroo, R. J. Arthern and C. K. Shum. 1998. Antarctic elevation change 1992 to 1996. Science, 282(5388), 456-458. 